\title{
World Economy after the Global Crisis
}

\author{
A New Economic Order
} for the 21st Century 


\title{
World Scientific Studies in International Economics
}

(ISSN: 1793-3641)

\author{
Series Editor Robert M. Stern, University of Michigan and \\ University of California-Berkeley, USA
}

Editorial Board Vinod K. Aggarwal, University of California-Berkeley, USA

Alan Deardorff, University of Michigan, USA

Paul DeGrauwe, Katholieke Universiteit Leuven, Belgium

Barry Eichengreen, University of California-Berkeley, USA

Mitsuhiro Fukao, Keio University, Tokyo, Japan

Robert L. Howse, New York University, USA

Keith E. Maskus, University of Colorado, USA

Arvind Panagariya, Columbia University, USA

Published*

Vol. 13 Light the Lamp

Papers on World Trade and Investment in Memory of Bijit Bora edited by Christopher Findlay (University of Adelaide, Australia), David Parsons (KADIN Indonesia) \& Mari Pangestu (Trade Minister of Indonesia)

Vol. 14 The International Financial Crisis: Have the Rules of Finance Changed?

edited by Asli Demirgüç-Kunt (The World Bank, USA),

Douglas D Evanoff (Federal Reserve Bank of Chicago, USA) \&

George G Kaufman (Loyola University of Chicago, USA)

Vol. 15 Systemic Implications of Transatlantic Regulatory Cooperation and Competition edited by Simon J Evenett (University of St Gallen, Switzerland) \& Robert M Stern (University of Michigan, USA)

Vol. 16 Comparative Advantage, Growth, and the Gains from Trade and Globalization A Festschrift in Honor of Alan V Deardorff edited by Robert M Stern (University of Michigan, USA)

Vol. 17 Macroprudential Regulatory Policies: The New Road to Financial Stability? edited by Stijn Claessens (International Monetary Fund, USA), Douglas D Evanoff (Federal Reserve Bank of Chicago, USA), George G Kaufman (Loyola University Chicago, USA) \& Laura Kodres (International Monetry Fund, USA)

Vol. 18 Quantitative Analysis of Newly Evolving Patterns of International Trade: Fragmentation, Offshoring of Activities, and Vertical Intra-Industry Trade edited by Robert M Stern (University of Michigan and University of California-Berkeley, USA)

Vol. 19 The World Economy after the Global Crisis: A New Economic Order for the 21st Century edited by Barry Eichengreen (University of California-Berkeley, USA) \& Bokyeong Park (Korea Institute for International Economic Policy, Korea)

*The complete list of the published volumes in the series can be found at http://www.worldscibooks.com/series/wssie_series.shtml. 


\section{World Economy after the Global Crisis}

\section{A New Economic Order for the 21st Century}

Editors

\section{Barry Eichengreen}

University of California, Berkeley, USA

\section{Bokyeong Park}

Korea Institute for International Economic Policy, Korea 


\section{Published by}

World Scientific Publishing Co. Pte. Ltd.

5 Toh Tuck Link, Singapore 596224

USA office: 27 Warren Street, Suite 401-402, Hackensack, NJ 07601

UK office: 57 Shelton Street, Covent Garden, London WC2H 9HE

\section{Library of Congress Cataloging-in-Publication Data}

The world economy after the global crisis : a new economic order for the

21st century / edited by Barry Eichengreen \& Bokyeong Park.

p. cm. -- (World scientific studies in international economics, ISSN 1793-3641 ; v. 19)

Includes bibliographical references and index.

ISBN-13: 978-9814383035

ISBN-10: 9814383031

1. Global Financial Crisis, 2008-2009. 2. Economic history--21st century.

I. Eichengreen, Barry J. II. Pak, Pog-yong.

HB3722.W673 2012

330.9--dc23

2012005344

\section{British Library Cataloguing-in-Publication Data}

A catalogue record for this book is available from the British Library.

Copyright (C) 2012 by World Scientific Publishing Co. Pte. Ltd.

All rights reserved. This book, or parts thereof, may not be reproduced in any form or by any means, electronic or mechanical, including photocopying, recording or any information storage and retrieval system now known or to be invented, without written permission from the Publisher.

For photocopying of material in this volume, please pay a copying fee through the Copyright Clearance Center, Inc., 222 Rosewood Drive, Danvers, MA 01923, USA. In this case permission to photocopy is not required from the publisher.

In-house Editor: Alisha Nguyen

Typeset by Stallion Press

Email: enquiries@stallionpress.com

Printed in Singapore. 


\section{Acknowledgments}

This book has its origins in a research project initiated by the Korea Institute for International Economic Policy (KIEP), Korea's leading think tank. It was organized with the goal of analyzing changes in the world economy since the global financial crisis from a variety of economic, functional and analytical perspectives. The editors would like to thank KIEP for its financial support, which was essential to completion of the project and publication of this book.

The Korea Institute for International Economic Policy (KIEP) was founded in 1989 as a government-funded independent economic research institute. KIEP carries out research on the East Asian economies various aspects of world economy, such as international finance, open macroeconomics, trade and investment. KIEP advises the government on all major international economic policy issues. 
This page intentionally left blank 


\section{Contents}

Acknowledgments $\quad$ v

Contributors xi

Chapter 1. Introduction 1

$\begin{array}{lll}\text { Chapter 2. Financial Reform after the Crisis } & \mathbf{7}\end{array}$

1 Introduction . . . . . . . . . . . 7

2 The Dynamics of Financial Reform . . . . . . . 9

2.1 The G20 . . . . . . . . . . . . . . . . . 10

2.2 The IMF and the FSB $\ldots \ldots \ldots \ldots$

2.3 Individual jurisdictions $\ldots \ldots \ldots \ldots$

2.4 Crisis-induced shifts . . . . . . . . . . . 15

3 Challenges and Outlook . . . . . . . . . . . . . 18

3.1 Ongoing crisis management . . . . . . . . . . . . 19

3.2 Macroprudential approaches . . . . . . . . 21

3.3 Regulating multinational financial firms . . . . 23

3.4 Consistent implementation of global standards 24

3.5 Financial systems and growth . . . . . . . . 25

References . . . . . . . . . . . . . 26

Chapter 3. Did WTO Rules Restrain Protectionism During the Recent Systemic Crisis? 29

1 Introduction . . . . . . . . . . . . . . 29

2 Twenty-First Century Protectionism During a

Systemic Financial Crisis: Some Preliminary

Considerations . . . . . . . . . . . . . . . 32

3 The Resort to Discrimination Against Foreign

Commercial Interests Since the First Crisis-Era G20

Summit in November 2008 . . . . . . . . . . . . 40 
4 An Assessment of the Impact of WTO Rules During the Recent Systemic Crisis . . . . . . . . . . . 65

5 Concluding Remarks . . . . . . . . . . . . . 73

References . . . . . . . . . . . . . . . . . . 74

Chapter 4. The International Monetary System after the Financial Crisis $\quad \mathbf{7 7}$

1 The Global Reserve System _. . . . . . . . . . . . 79

2 The Emergency Provision of Liquidity . . . . . . 85

3 Regulating Capital Flows . . . . . . . . . . . . . 90

4 The Role of the IMF . . . . . . . . . . . . . . . 93

5 Conclusion . . . . . . . . . . . . . . 97

References . . . . . . . . . . . . . . . 98

Chapter 5. The Group of 20: Trials of Global

Governance in Times of Crisis

1 Benefits from International Coordination:

Reviewing the Arguments . . . . . . . . . . . . 104

2 A Narrative of the G20 in Times of Crisis . . . . 106

2.1 Washington (November 2008) . . . . . . 106

2.2 London (April 2009) . . . . . . . . . . . . . . 109

2.3 Pittsburgh (September 2009) . . . . . . . . . 111

2.4 Toronto and Seoul (June and November 2010) . . . . . . . . . . . . . . . 113

2.5 Cannes (November 2011) . . . . . . . . . . . . . 117

3 Scoreboards of Success . . . . . . . . . . . . . . 121

4 Taking Stock and Looking Forward . . . . . . . . 124

References . . . . . . . . . . . . . . . . . 127

Chapter 6. Emerging Markets in the Aftermath of the Global Financial Crisis 129

1 Introduction . . . . . . . . . . . . . . . . 129

2 Rising Prominence of EMEs . . . . . . . . . . . . 131

3 The Distribution of World Growth . . . . . . . . 136

4 What Explains the Resilience of Emerging Markets? . . . . . . . . . . . . . . . . . 140

5 Global Public Debt and Implications for the Growth Gap . . . . . . . . . . . . . . . . . 143

6 Risks . . . . . . . . . . . . . . . . . . 147

7 Concluding Remarks . . . . . . . . . . . . . . . 149

References . . . . . . . . . . . . . . 150 
Chapter 7. Challenges for Emerging Asia

1 Introduction: Asia's Recovery from the Global Financial Crisis . . . . . . . . . . . . . 153

2 Transition from Exports to Domestic Demand . . . 157

3 Killing the Inflation Dragon . . . . . . . . . . . . 160

4 Risk of the Middle Income Trap . . . . . . . . . . 162

5 The Rise of China and the Future of Regional Cooperation . . . . . . . . . . . 167

6 Conclusion . . . . . . . . . . . . . . . . . 169

References . . . . . . . . . . . . . . . . 170

Chapter 8. Long-Term Challenges for the Advanced Economies: Reducing Government Debt 173

1 Introduction . . . . . . . . . . . . . . . . 173

2 Projected Paths of Government Debt . . . . . . . 175

2.1 General government primary balances . . . . . 175

2.2 Size of economies (GDP) . . . . . . . . 177

2.3 Interest rates . . . . . . . . . . . . . . . . 177

2.4 Baseline debt projections . . . . . . . . . . 178

2.5 The optimistic and pessimistic health care cost scenarios . . . . . . . . . . . . . 184

2.6 Two interest rate scenarios . . . . . . . . . 185

2.7 The optimistic growth scenario . . . . . . . . 186

2.8 The pessimistic growth scenario . . . . . . 187

2.9 Implications of net debt projections . . . . . 188

3 The Burden of Debt and Fiscal Limits . . . . . . . 188

3.1 Effect of debt on interest rates and interest payments . . . . . . . . . . . . . . . 189

3.2 The limits of debt . . . . . . . . . . . . . . . . . . . . 192

3.3 Fiscal crises . . . . . . . . . . . . . . . . 196

4 Paths to Safety . . . . . . . . . . . . . . 200

4.1 Gradual (early) adjustment . . . . . . . . . . 202

4.2 Abrupt (delayed) adjustment . . . . . . . . . . 203

4.3 Benefits of early and gradual adjustment . . . 204

5 Conclusion . . . . . . . . . . . . . . . 204

References . . . . . . . . . . . . . . 205 
This page intentionally left blank 


\section{Contributors}

Ignazio Angeloni is Advisor to the Executive Board of the ECB and Visiting Fellow of Bruegel, the Brussels think tank. Previously he was Director for International Financial Affairs at the Ministry of Economy and Finance of Italy, in which position he was also a member of the G20 Deputies. Before that, he was Deputy Director General of Research at the European Central Bank and Director of Monetary and Financial Research in the Bank of Italy. He holds a $\mathrm{PhD}$ from the University of Pennsylvania and a Bachelor's degree from Bocconi University.

His research focuses on monetary policy issues, the links between financial stability and monetary policy and European monetary and financial integration. He is the author of books and of articles that have appeared in top US and European academic journals.

Barry Eichengreen is George C. Pardee and Helen N. Pardee Professor of Economics and Political Science at the University of California Berkeley. He is Research Associate of the National Bureau of Economic Research and Research Fellow of the Centre for Economic Policy Research.

His most recent books are Exorbitant Privilege: The Rise and Fall of the Dollar and the Future of the International Monetary System (2011), Emerging Giants: China and India in the World Economy, co-edited with Poonam Gupta and Ranjiv Kumar (2010), Labor in the Era of Globalization, co-edited with Clair Brown and Michael Reich (2009), Institutions for Regionalism: Enhancing Asia's Economic Cooperation and Integration, co-edited with Jong-Wha Lee (2009), and Fostering Monetary \& Financial Cooperation in East Asia, co-edited with Duck-Koo Chung (2009). Other books include Globalizing Capital: A History of the International Monetary System, Second Edition (2008), The European Economy Since 1945: Coordinated Capitalism and Beyond (updated paperback edition, 2008), Bond 
Markets in Latin America: On the Verge of a Big Bang?, co-edited with Eduardo Borensztein, Kevin Cowan, and Ugo Panizza (2008), and China, Asia, and the New World Economy, co-edited with Charles Wyplosz and Yung Chul Park (2008).

Simon J. Evenett is Academic Director of MBA programmes at the University of St. Gallen, Switzerland, where he is Professor of International Trade and Economic Development in the Department of Economics. He is also Programme Director of the International Trade and Regional Economics Programme of the Centre of Economic Policy Research. Professor Evenett is an expert in the commercial policies and strategies of the US, EU, and rising economic powers such as China. He has published over 125 journal articles, book chapters, and books and is a frequent public lecturer, including speaking to corporate executives about international business strategy. Professor Evenett also coordinates the worldwide protectionist monitoring service, Global Trade Alert.

Joseph E. Gagnon is Senior Fellow of the Peterson Institute for International Economics since September 2009. He was Visiting Associate Director, Division of Monetary Affairs (2008-2009) at the US Federal Reserve Board. Previously he served at the US Federal Reserve Board as Associate Director, Division of International Finance (1999-2008), and senior economist (1987-1990 and 1991-1997). He has also served at the US Treasury Department (1994-1995 and 1997-1999) and has taught at the University of California's Haas School of Business (1990-1991). He is author of Flexible Exchange Rates for a Stable World Economy (2011) and The Global Outlook for Government Debt Over the Next 25 Years: Implications for the Economy and Public Policy (2011). He has published numerous articles in economics journals, including Journal of International Economics, Journal of Monetary Economics, Review of International Economics, and Journal of International Money and Finance, and has contributed to several edited volumes.

Marc Hinterschweiger has been a Research Analyst with the Peterson Institute since 2008. $\mathrm{He}$ is also $\mathrm{PhD}$ candidate in economics at Ludwig-Maximilians University (LMU) in Munich, Germany. His research focuses on the transmission mechanism of monetary policy, asset prices, and financial crises. He previously worked at the Rhenish-Westfalian Institute for Economic Research (RWI) in Essen, Germany. He assisted 
Joseph E. Gagnon with Flexible Exchange Rates for a Stable World Economy and The Global Outlook for Government Debt over the Next 25 Years: Implications for the Economy and Public Policy (2011).

Jinill Kim is Professor of Economics at Korea University, where he has taught since 2010. Dr. Kim received his B.A. in Economics from Seoul National University in 1989 and his Ph.D. in Economics from Yale University in 1996. After working as Economist in the Division of Research and Statistics at the Federal Reserve Board for two years, he became an Assistant Professor at the University of Virginia in 1998. He returned to the Federal Reserve Board in 2003 and served as Economist and Senior Economist in the Monetary Affairs Division until 2011.

Bokyeong Park is Director of the International Economy Department at the Korea Institute for International Economic Policy (KIEP). He has conducted research on international finance and development cooperation at KIEP since 2002. He was a visiting scholar at UC Berkeley and Johns Hopkins University. While working at KIEP, he has also served as a member of advisory committees for the Presidential Office and the Ministry of Foreign Affairs and Trade of Korea. He received his B.A. and Ph.D. in Economics from Seoul National University.

Eswar S. Prasad is Tolani Senior Professor of Trade Policy and Professor of Economics at Cornell University. He is also Senior Fellow at the Brookings Institution, where he holds the New Century Chair in International Economics, and Research Associate at the National Bureau of Economic Research. He was previously chief of the Financial Studies Division at the IMF and before that head of the IMF's China Division. He is a member of an Advisory Committee to India's Finance Minister and Lead Academic for the International Growth Center's India Growth Research Program. He has testified before various US Congressional Committees at hearings on China. He is the creator of the Brookings-Financial Times Global Economy Index (Tracking Indicators for the Global Economy; www.ft.com/tiger). He is also Research Fellow at IZA (Institute for the Study of Labor, Bonn) and Research Associate of the National Asia Research Program.

Nicolas Véron is Senior Fellow at Bruegel, the Brussels-based international economy think tank, and Visiting Fellow at the Peterson Institute for International Economics in Washington DC. His research focuses on 
financial systems and regulation, including current developments in the European Union. He has been involved in the creation and development of Bruegel since 2002 and has divided his time since 2009 between Washington DC and Europe. A graduate of France's Ecole Polytechnique and Ecole des Mines, his earlier experience combines policy work as a senior French civil servant, and corporate finance as a junior investment banker, CFO of a small listed company, and independent strategy consultant. In 2006, he co-authored Smoke 83 Mirrors, Inc.: Accounting for Capitalism, and is also the author of several books in French. He writes a monthly column on European finance that is published by leading newspapers and online media in most G20 countries. 